Teeranantawanich, C., \& Phimolsathien, T. (2018). Thai legal practitioners'

knowledge management: Communications skills, professionalism, and

competency as the antecedents for success. Journal of International Studies, 11(1),

108-123. doi:10.14254/2071-8330.2018/11-1/8

\title{
Thai legal practitioners' knowledge management: Communications skills, professionalism, and competency as the antecedents for success
}

\author{
Cherdsak Teeranantawanich \\ Faculty of Administration and Management, \\ King Mongkut's Institute of Technology Ladkrabang (KMITL) \\ Thailand \\ asia.attorney@gmail.com \\ Thepparat Phimolsathien \\ Faculty of Administration and Management, \\ King Mongkut's Institute of Technology Ladkrabang (KMITL) \\ Thailand \\ thepparat@hotmail.com
}

Abstract. The purpose of this research was to examine the variables contributing to

Received: Thai legal practitioners' knowledge management abilities. By means of simple random-sampling, the sample of 332 individuals was surveyed using the 72 item, 7-level, Likert type agreement scale questionnaire on the study's four constructs. Confirmatory factor analysis was run prior to the structural equation model, with the analysis undertaken in LISREL 9.1. All causal factors in the model were shown to have a positive influence on knowledge management, with $92 \%$ variance of the factor affecting knowledge management (KM) (R2).

Ranked in importance were communications skills (CSK), competency (COMP), and professionalism (PRO), with the total mean score of 0.96, 0.43, and 0.34 , respectively.

Keywords: attorney, ethics, international trade, law, Thai Law Society.

JEL Classification: D83, F23, K4, K15, K33

\section{INTRODUCTION}

Over the past few decades the reputation of Thai private legal practitioners has seen considerable change in terms of Thai public opinion. Thirty years ago, Thai lawyers were assigned quite low on the social and economic status ladder (Chaimungkalanont, $\mathrm{n} / \mathrm{d}$ ). The major intention of those studying law was to become judges one day, however, getting to such lofty heights was only the cream rose for the few selected, while others were left just to practice law. Law and lawyers during this period were viewed as 
primarily involved in representing people in disputes, and those practices were held in disdain in Thai society.

Today however, Thailand has become a hub for various economic sectors' development, and international businesses and investments from abroad require a multi-jurisdictional, legal practice heavily reliant on legal practitioners and consultants (Chaimungkalanont, $\mathrm{n} / \mathrm{d}$ ). With this, the role of Thai lawyer has increased, but this also has brought great challenges to the profession in the sense of knowledge management hurdles and work in the changed cross-cultural and multi-lingual environment.

With the increase in numbers of Thai legal consultants providing information and recommendations on the matters ranging from international business operations to legal migration, one might think that this would have been a targeted profession by the Association of Southeast Asian Nations (ASEAN) when the mutual recognition arrangements (MRAs) were established for eight professional services. This however was not the case, and legal services and lawyers were not included (Fukunaga, 2015). In fact, at this time, it is difficult or impossible for a lawyer from one ASEAN country to practice law in another ASEAN country. Even though ASEAN countries have entered into commitments through the ASEAN Framework Agreement on Services, the ASEAN Economic Community Blueprint, and various ASEAN free trade agreements, ASEAN lawyers do not receive more favorable treatment in other ASEAN countries than lawyers from non-ASEAN countries (Krairit, $\mathrm{n} / \mathrm{d}$ ).

This therefore has been one element that has greatly limited the internationalization and knowledge management abilities of Thai legal professionals, and this, consequently, has led to complications in the relationships between Thai domestic firms and foreign enterprises. Globalization has also fueled a massive increase in the potential for exchange of goods, services, and communication, and the growing need for legal norms to facilitate the expansion of cross-border practices.

Therefore, the convergence of technology and economics has triggered new market demands within the legal profession. Law firms have always recognized that their value lies in their intellectual capital, or the ability of their lawyers to maximize their collective knowledge on behalf of their clients (Moore, 2017). Combined with a challenging and highly competitive economic climate, client expectations are forcing firms to be innovative in how they utilize their collective knowledge (Porter, 1979). This is the domain of knowledge management $(\mathrm{KM})$, and law firms are increasingly using it as a way to address challenges that range from general productivity to risk management and succession planning (Moore, 2017).

\section{LITERATURE REVIEW}

\subsection{Communication skills (CSK)}

The practice of law is highly dependent on good communication skills, especially persuasive verbal skills, with former US Chief Justice Warren Burger having repeatedly called upon the legal community to increase the study of communication skills in law schools (Kessler, 1998). Re (1982), also suggests that there should be more time devoted to teaching counseling skills in law schools, and that the legal counselor can play a crucial role in avoiding controversy and in resolving disputes without resorting to litigation.

Legal professionals also need to exhibit key skills, which includes good verbal communications, good listening, sound advice, openness, curiosity, value, and persuasion. Furthermore, according to the Sydney University Law Society Careers Guide (2014), the selection criteria common to many legal graduates include planning and organizing, team-work abilities, excellent written and oral communication skills, and problem-solving, and data analysis skills. 
Francis (2016) stated that law firms in the United Kingdom placed a high importance on 'personality' or 'commercial awareness', which was as important or maybe more so, than academics. Furthermore, law partners were stated to say that a legal candidate can have the best academic record in the world but if they can't hold a conversation in an interview, then they serve no usefulness to the firm. So specifically, firms place a high priority on communication skills, motivation and drive, work ethic, organizational and planning skills, teamwork, imitative, presentation skills, and overall passion.

Another form of "communications" for the legal profession also involves the technological tools used. Before the internet age, lawyers communicated with their clients by use of personal meetings, over the phone, and by mail. Later came the fax machine which was added to the mix (only after much deliberation concerning its security and legality), and then in the mid-1990s, email became commonplace, and lawyers quickly adapted to this new form of electronic communication (Black, 2017a). However, security with these devices has reared its ugly head, as protection of the "attorney/client privilege" is still of paramount concern.

Today, "cloud" collaboration has become the trend, along with the ever-present smartphone. In this latest environment, secure, encrypted, web-based computing (the cloud) is becoming the trend, with 38\% of the legal professionals surveyed in 2016 by the American Bar Association reporting its use (Black, 2017a). Lawyers are also increasingly communicating and collaborating with their clients online, and according to the report, $33 \%$ of lawyers now share documents with their clients online, while $26 \%$ report using online messaging and communication tools with their clients.

Given the extent and pace of change in communications mediums, legal professionals need to seize the day and take advantage of the unique opportunities presented by technology. Due to client awareness and use of technology, there has also been an associated sudden shift in expectations that has dramatically increased competition in the legal services space, creating an astounding effect on the delivery of legal services (Black, 2017b), such as LegalZoom and Rocket Lawyer.

From the above theories and scholars' concepts of communications skills (CSK), the following frequently discussed items were included in the study. They included types skills (SKILLS), communications tools (TOOLS), and the counseling environment (ENV), and were therefore placed into the research framework. From this, the following hypothesis concerning communications skills (CSK), was developed:

H1: Communications Skills (CSK) has a direct and positive influence on Competency (COM).

H2: Communications Skills (CSK) has a direct and positive influence on Knowledge Management (KM).

H3: Communications Skills (CSK) has a direct and positive influence on Professionalism (PRO).

\subsection{Competitiveness (COM)}

Flanagan's (1954) introduced the concept of the 'Critical Incidents Technique', which is thought of today as a key methodology in competency studies. Out of this, McClelland (1973) introduced the term 'competency', and the separation of 'competency' and 'intelligence'. Later researchers such as Gipps and Stobart (2003), defined 'competent', as educational training and experience, rather than a natural feature such as intelligence. This is consistent with Francis (2016), which examined legal job applicants in the United Kingdom, and stated that previous legal experience was often ranked as second or third most important in a recruiter's assessment. Boyatzis (1982) subsequently introduced competency modeling which discussed the importance of systematic analysis. Boyatzis also introduced the behavioral event interview (BEI), known to many job seekers around the world.

Myatt (2013) emphasized the importance of personal competency over technical competency, and a worker's "soft skills", with leadership discussed in terms of closing gaps, not creating them. Giusti (2008) 
confirmed this for legal profession and stated that soft skills for lawyers and the ability to deal with people effectively and politely, has a tremendous influence on professional success of a lawyer.

On an intercultural level, Matveev's (2016) Collaborative Intercultural Competence Model (CICM), emphasizes the importance of how to work and relate effectively in an intercultural context. Deardorff (2009) also noted the lack of second-language learning and overseas experience in competency in his research.

Mansfield (1989) also indicated the importance of competency by stating it is the key to vocational and education training (VET). This is consistent with directives from the European Union (2015), which state that there needs to be relevant and high-quality knowledge, skills and competences developed throughout lifelong learning, which focuses on learning outcomes for employability, innovation, active citizenship, and well-being (Reeve, 2016).

From the above theories and scholars' concepts of competency, competency (COM) was frequently discussed in terms of five components. These included client satisfaction (CS), service demand (SER), responsiveness (REP), revenue (REV), and celebrity (CEL), and were therefore placed into the research framework. From this, the following hypotheses concerning COM were developed:

H4: Competency (COM) has a direct and positive influence on Knowledge Management (KM).

H5: Competency (COM) has a direct and positive influence on Professionalism (PRO).

\subsection{Professionalism (PRO)}

In Thailand, according to Section 35 of the Thailand Lawyers Act B.E. 2528 (1985), a legal professional's qualifications include being a Thai national, being at least twenty years of age, not having gone to prison, not having been bankrupt, not having an ailment which is contagious and repugnant to the public, or being mentally ill. Also, although you cannot have indecent behavior or delinquent morals (Section 4), you can however be a politician (section 10). Pertaining to education, a legal professional is expected to have a Bachelor's Degree, or an Associate Degree in law, or a certificate in law equivalent to a Bachelor's Degree or Associate Degree from an educational institute accredited by the Law Society of Thailand. Also, the individual must also be a member of the Thai Bar Association.

Francis (2016) examined legal professionalism and noted that essentially all law firms are the same when it comes to hiring young law graduates, whose criteria was excellent 'academics', a well-rounded personality with a multitude of extracurricular activities, previous legal work experience, and an ability to "fit" within a firm. This is consistent with Duff et al. (2000), which indicated achieving a Graduate Diploma in Law (GDI) in the United Kingdom as a key variable for employment success for non-law graduates wishing to become a solicitor or barrister.

Originally, Thailand embraced ethical concepts in the legal profession from India, as appeared in the Indapas Principles and the Law of the Judicial Procedures, which combined good norms and Buddhist beliefs with a policy of political administration (Jayaphorn, 2006; Mahakun et al., 2017). Subsequently, Thailand adopted the Law of the Three Seals, and later due to Western trade, Thailand's administrative system, legal system, and culture were reformed along Western lines.According to Maister (2000), the difference between a "really professional" consultant and an ordinary consultant, is not technical qualifications and analytical skills, but instead the right attitudes and behavior, with integrity (ethics) being central to the idea of professionalism. Also, integrity is seen as vigorously enforcing values, standards and principles, whose end-result is the achievement of the best brand names and the highest profits (Maister, 2003). This is in agreement with Ryan et al. (2012), which concluded that business unit profitability could be accounted for by four competencies, specifically team leadership, developing others, achievement orientation, and impact and influence.

In Thailand, to be registered and to obtain a lawyer's license, the candidate must complete training in professional ethics and the basic principles of advocacy and the legal profession. The training course, run 
by the Institute of Law Practice Training of the Law Society of Thailand, is usually divided into two terms. In the first term, the candidate has to learn the theory of case conduct and professional ethics for not less than 90 hours (Sathitsuksomboon, 2001). In the second term, he/she must practice working in a qualified law office for at least six months. An examination will be held at the end of each term. After completion of the training course, a candidate may apply for membership in the Law Society of Thailand. Exceptions can be made to the training course if a candidate has over a year experience in a law firm and has passed an examination given by the Law Society of Thailand (Palma, 2015).

From the above theories and scholars' concepts of legal practitioners and consultants' professionalism (PRO), the following frequently discussed items were included in the study. They included specialized knowledge (SK), systems thinking (SYS), experience (EXP), and ethics (ETH), and were therefore placed into the research framework. From this, the following hypothesis concerning professionalism was developed:

H6: Professionalism (PRO) has a direct and positive influence on Knowledge Management (KM).

\subsection{Knowledge management (KM)}

Traditional methods of managing human capital, innovation, and learning within organizations, particularly law firms, have proven ineffective as they often fail to contribute to a firm's success (Kabene et al., 2006). Gomes (2001) strongly believes that knowledge is an asset and should be managed, in a similar fashion to the traditional cash flow, human resources, or raw materials.

In the UK market for legal services, a successful approach to international strategy development involved a "processual" approach. Using this strategy, the client was involved to a significant degree with the approach relying on expert (specific) knowledge of relevant markets as well as specialized knowledge rooted in legal and financial disciplines (Nonaka, 2005).

Today, law firms face an increasingly competitive market due to increased specialization and a need to compete globally (Kabene et al., 2006). Among other things, these forces have reiterated the value of knowledge within the industry. According to Lambe (2003), large law firms today recognize that they are in a knowledge business, and they too suffer from the challenges of connectivity, globalization, and speed. As a result, major law firms must share knowledge more efficiently and more effectively than ever before. In order to do so, many law firms are turning to KM for a solution, with formal knowledge management and their related software systems organizing that knowledge to make it more readily accessible (Black, 2017a, 2017b; Buckler, 2004). Furthermore, KM especially helps junior lawyers “acquire good road maps", as compared to having to learn "the road" through years of experience. It also helps firms capture senior lawyers' knowledge before they retire.

From the above theories and scholars' concepts of knowledge management, the following frequently discussed items were included in the study. They included types (TYPES), data and Information (DAI), knowledge management (KMA), specialized knowledge (SK), and systems thinking (SYS), and were therefore placed into the research framework.

\subsection{Conceptual framework}

Based on the above hypotheses and review of the literature, the researchers have developed Figure 1's conceptual framework which includes the causal relationships between competency, professionalism, communications skills, and of Thai legal practitioners' knowledge management. 


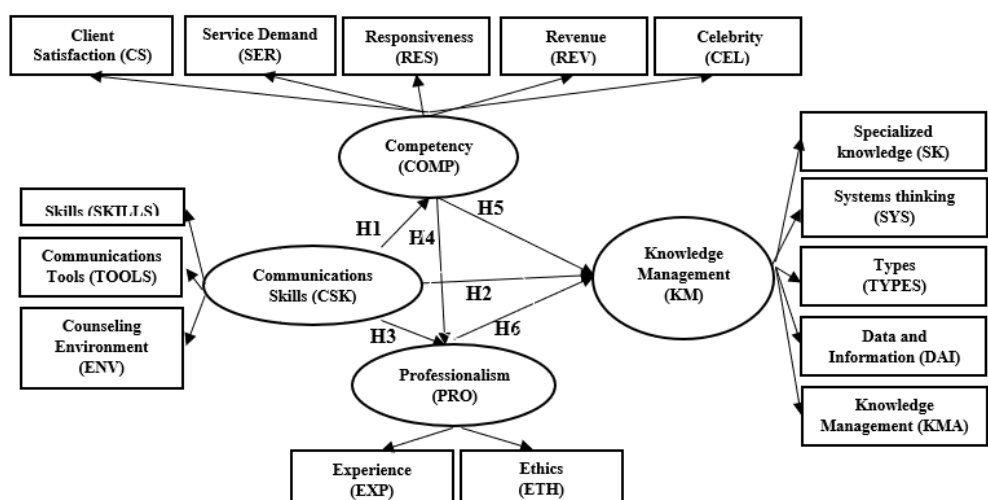

Figure 1. Conceptual model

\section{METHODOLOGY}

\subsection{Sample and data collection}

The sample population or unit of analysis for this research included questionnaires obtained between August to December 2016 from 332 Thai legal practitioners and consultants (Hair et al., 2016). The population of this study was 78,142 Thai legal practitioners and consultants who were members of the Thai Law Society in 2015, and who worked as in-house (corporate) lawyers, lawyers of state-owned enterprises, in private law firms, or who were 'freelancers'.

Table 1

Summary of Latent and Observed Variables and Their Associated References

\begin{tabular}{|c|c|c|}
\hline Latent Variables & Observed variables (15 items) & Knowledge Base (Theory) \\
\hline $\begin{array}{l}\text { Communications } \\
\text { Skills (CSK) }\end{array}$ & $\begin{array}{l}\text { Skills (SKILLS) } \\
\text { Communications tools (TOOLS) } \\
\text { Counseling environment (ENV) }\end{array}$ & $\begin{array}{l}\text { Black, 2017a, Black, 2017b; Francis, 2016; } \\
\text { Gunashekar, 2017; Kessler, 1998; National } \\
\text { Association of Colleges and Employers, 2015; Re, } \\
\text { 1982; Shannon, 2011; Sydney University Law Society } \\
\text { Careers Guide, 2014. }\end{array}$ \\
\hline $\begin{array}{l}\text { Competency } \\
\text { (COMP) }\end{array}$ & $\begin{array}{l}\text { Client Satisfaction (CS) } \\
\text { Service demand (SER) } \\
\text { Responsiveness (REP) } \\
\text { Revenue (REV) } \\
\text { Celebrity (CEL) }\end{array}$ & $\begin{array}{l}\text { Boyatzis, 1982; Deardorff, 2009; European Union, } \\
\text { 2015; Flanagan, 1954; Francis, 2016; Gipps \& Stobart, } \\
\text { 2003; Giusti, 2008; Mansfield, 1989; Matveev, 2016; } \\
\text { McClelland, 1973; Myatt, 2013; Reeve, 2016; }\end{array}$ \\
\hline $\begin{array}{l}\text { Professionalism } \\
(\mathrm{PRO})\end{array}$ & $\begin{array}{l}\text { Experience (EXP) } \\
\text { Ethics }(\mathrm{ETH})\end{array}$ & $\begin{array}{l}\text { Chaimungkalanont, n/d; Duff et al., 2000; Francis, } \\
\text { 2016; Jayaphorn, 2006; Legal Services Commission, } \\
\text { 2017; Mahakun et al., 2017; Maister, 2000, 2003; Ryan } \\
\text { et al., 2012.; Thailand Lawyers Act B.E. 2528, } 1985 .\end{array}$ \\
\hline $\begin{array}{l}\text { Knowledge } \\
\text { Management (KM) }\end{array}$ & $\begin{array}{l}\text { Types (TYPES) } \\
\text { Data and Information (DAI) } \\
\text { Knowledge Management (KMA) } \\
\text { Specialized knowledge (SK) } \\
\text { Systems thinking (SYS) }\end{array}$ & $\begin{array}{l}\text { Black, 2017a, 2017b; Buckler, 2004; Kabene et al., } \\
\text { 2006; Gomes, 2001; Lambe, 2003; Moore, 2017; } \\
\text { Nonaka, 2005; Porter, 1979; Sathitsuksomboon, } 2001 .\end{array}$ \\
\hline
\end{tabular}

The research method used a 72-item instrument to assess the four constructs in the knowledge management model. All questionnaire items used a 7-point response format (Likert 1972). The questionnaire was administered to 332 individuals involved as practitioners and consultants within the 
Thai legal profession. The questionnaire was developed from the literature review and related theory, and was constructed as a tool to measure concept definition and practice (Table 1).

\subsection{Reliability}

Five legal experts determined the reliability of the questionnaire so as to ensure that the responses were reliable and consistent. A trial assessment of 25 questionnaires was conducted prior to the actual survey to determine questionnaire reliability and consistency. The reliability value was calculated by using Cronbach's $\alpha$ (Tavakol \& Dennick, 2011) to ensure internal consistency within the items. George and Mallery (2010) indicated the value of Coefficient Cronbach's $\alpha$ as $\alpha \geq 0.9=$ excellent, and $\geq 0.8=$ good. In general, a score of $\geq 0.7$ is considered acceptable, although some authors suggest higher values of 0.90 0.95 (Tavakol \& Dennick, 2011). From even the most stringent criteria of Cronbach's $\alpha$ the study's questionnaires were deemed to be reliable as the score was 0.958 .

Furthermore, the questionnaire was divided into two parts, with Part 1 consisting of five items concerning the legal consultant's general and personal information, while Part 2 consisted of the actual questionnaire concerning the legal consultant's views concerning the elements which make up knowledge management within the Thai legal profession. Respondents were required to determine the degree to which each statement reflected knowledge management by use of a Likert type agreement scale (Likert, 1972) ranging from 1 (strongly disagree) to 7 (strongly agree). Therefore, from the seven levels of frequency, the interpretation of these responses was calculated by using the formula:

Interval $=\frac{\text { the highest score }- \text { the lowest score }}{\text { the number of interval }}$. From the calculations, the interval level for the seven levels of frequency were $6.14-7.00$ (I think this is extremely important), $5.28-6.14$ (I think this is very important), and $4.42-5.28$ (I think this is important). Lower scores were not relevant as the respondents did not use them.

\subsection{Statistical analyses overview}

To test the proposed research model, the researchers adopted the survey method for data collection, whose hypotheses were examined by use of Lisrel (linear structural relations) 9.1 to the collected data (Jöreskog et al., 2016). Measurement and data collection implies an evaluation of the measurement model. Additionally, the measurement model in this research was analyzed in three stages: 1) the individual item reliabilities, 2) the model's convergent validity, and 3) discriminant validity.

Individual item reliability was examined by looking at the loadings, or correlations, of each indicator on its respective construct. For reflective indicators, it is generally accepted that items must have a factorial load $(\lambda)$ of 0.707 or above, and all values have been statistically significant $(|t| \geq 1.96)$, representing convergent validity of scales. This threshold implies that there is more variance shared between the measures and their constructs that there is error variance. Reliability for the derived scale scores was also measured via internal consistency coefficient $\alpha$ (Tavakol \& Dennick, 2011).

\subsection{Qualitative data analysis}

Sample size suggestion usually depend on the complexity of the specified model, but 20 questionnaires per observed variable, with an overall sample size of $n=200$ cases, is considered reliable (UCLA Statistical Consulting Group, 2016). Therefore, from the above and other reviewed theory, a ratio of 20:1 was chosen as a sample goal, with the actual 332 individuals for the 15 observed variables (15x $20=300$ ) determined as highly reliable. 


\subsection{Confirmatory factor analysis}

To access the measurement models, a confirmatory factor analysis (CFA) is used followed by structural equation modeling (SEM) to examine the general fit of the proposed model with data, and to identify the overall relationships among these constructs (Fan et al., 2016). Wong (2013) also noted that for marketing research, a significance level of $5 \%$, a statistical power of $80 \%$, and $\mathrm{R}^{2}$ values of at least 0.25 are considered normal. Standard modelling accepts the proposed model if the $p$-value is higher than 0.05 , and if the $\mathrm{x}^{2} / \mathrm{df}$ ratio is less than two (Kline, 1998). Additionally, another common reported statistic is to use the root mean square error of approximation (RMSEA), as a measure of goodness-of-fit in SEMs (Chen et al., 2008) and to measure the discrepancy per degree of freedom (Hu \& Bentler, 1999). Hooper et al. (2008) indicated that items with low multiple $\mathrm{R}^{2}$ values $(\leq 0.20)$ should be removed from an analysis as this is an indication of very high levels of error, while Hair et al. (2016) suggested a higher cutoff of 0.25 .

\section{EMPIRICAL RESULTS AND DISCUSSION}

\subsection{Respondents' characteristics}

From the final sample of 332 individuals (Table 2), it was determined that $61.75 \%$ were male, and $38.25 \%$ were female. All had achieved at least a law degree at the undergraduate level $(80.12 \%)$, while $19.88 \%$ had obtained graduate degrees. Also, $38.86 \%$ were under the age of 35 which might be a contributing factor to the fact that $47.59 \%$ were 'freelance' legal consultants. All surveys were conducted face-to-face between 09.00 - 17.00 at either a provincial court, a university campus, the Lawyers' Council offices, or law firms where the respondents' practiced.

Table 2

Respondents Characteristics ( $\mathrm{n}=332$ )

\begin{tabular}{|c|c|c|}
\hline Gender & Frequency & $\%$ \\
\hline Male & 205 & 61.75 \\
\hline Female & 127 & 38.25 \\
\hline \multicolumn{3}{|l|}{ Age } \\
\hline Under 35 years old & 129 & 38.86 \\
\hline Between 36-45 & 97 & 29.22 \\
\hline Between 46-55 & 64 & 19.28 \\
\hline Between 56-70 & 35 & 10.54 \\
\hline Over 70 years old & 7 & 2.11 \\
\hline \multicolumn{3}{|l|}{ Education Level } \\
\hline Bachelor & 266 & 80.12 \\
\hline Masters & 60 & 18.07 \\
\hline $\mathrm{PhD}$ & 6 & 1.81 \\
\hline \multicolumn{3}{|l|}{ Profession } \\
\hline private sector employee & 31 & 9.34 \\
\hline Employee of state-owned enterprise & 34 & 10.24 \\
\hline Private business & 106 & 31.93 \\
\hline Freelance & 158 & 47.59 \\
\hline Other & 3 & 0.90 \\
\hline \multicolumn{3}{|l|}{ Position } \\
\hline Business owner & 51 & 15.36 \\
\hline Executive (CEO, Managing Director, etc.) & 17 & 5.12 \\
\hline Middle-level executive & 6 & 1.81 \\
\hline Manager & 14 & 4.22 \\
\hline
\end{tabular}




\begin{tabular}{|c|c|c|}
\hline In-house lawyer & 128 & 38.55 \\
\hline Other & 116 & 34.94 \\
\hline \multicolumn{3}{|c|}{ Legal Experience } \\
\hline Less than 5 years & 131 & 39.46 \\
\hline 5-10 years & 69 & 20.78 \\
\hline $11-15$ years & 35 & 10.54 \\
\hline $16-20$ years & 40 & 12.05 \\
\hline Over 20 years' experience & 57 & 17.17 \\
\hline
\end{tabular}

\subsection{Respondents' information}

Table 3 shows that the factors that affect Thai legal consultant's knowledge management (KM), which includes professionalism (PRO), competency (COM), and communications skills (CSK). Interpreted results from the 7-point survey which ranged from 5.19 - 5.68 (Best \& Kahn, 2003; Likert, 1972).

Table 3

Thai Legal Consultant Knowledge Management using the Likert Scale Interpretation

\begin{tabular}{|l|c|c|l|}
\hline Latent Variables & $\overline{\mathrm{x}}$ & S.D. & \multicolumn{1}{|c|}{ Interpretation } \\
\hline Knowledge Management (KM) & 5.51 & 1.18 & I think this is very important. \\
\hline Professionalism (PRO) & 5.68 & 1.30 & I think this is very important. \\
\hline Competency (COMP) & 5.19 & 1.36 & I think this is important. \\
\hline Communications Skills (CSK) & 5.51 & 1.28 & I think this is very important. \\
\hline
\end{tabular}

$\overline{\mathrm{x}}=$ the standard mean, S.D. $=$ Standard Deviation.

\subsection{Confirmatory factor analysis (CFA) results}

CFA analysis of the dependent and independent variables was built on the conceptual framework derived from the study of relevant documents and scholarly research (Figure 2 and Figure 3). By analyzing the confirmatory components with LISREL 9.1, $\chi 2$ was determined to not be statistically significant $(\mathrm{p}>$ 0.05 ), $\chi 2 / \mathrm{df}$ was $<2.00$, RMSEA $<0.05$, and standardized root mean square residual (SRMR) $<0.05$. The goodness-of-fit index (GFI) was also indicated to be 0.99 , and the adjusted goodness-of-fit index (AGFI) was 0.99, which indicates a well-fitting model as their values are greater than 0.90 (Hooper et al., 2008).

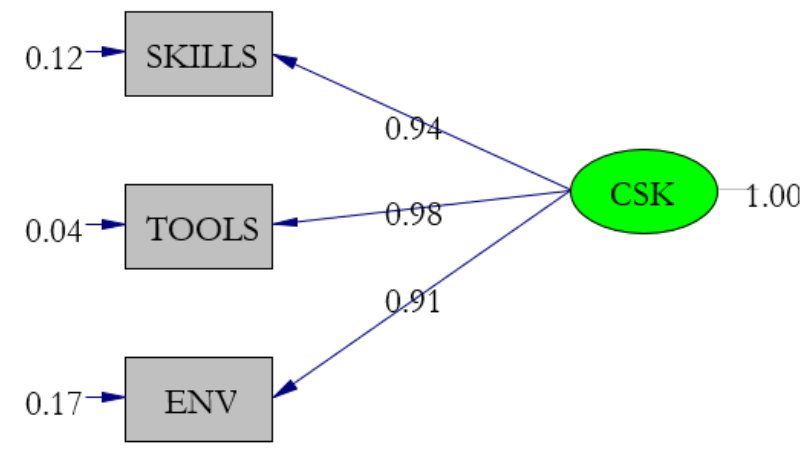

Figure 2. Confirmatory factor analysis of the external latent variables

Chi-Square $(\chi 2)=0.00, \mathrm{df}=0, p$ value $=1.00000, \mathrm{RMSEA}=0.000$. 


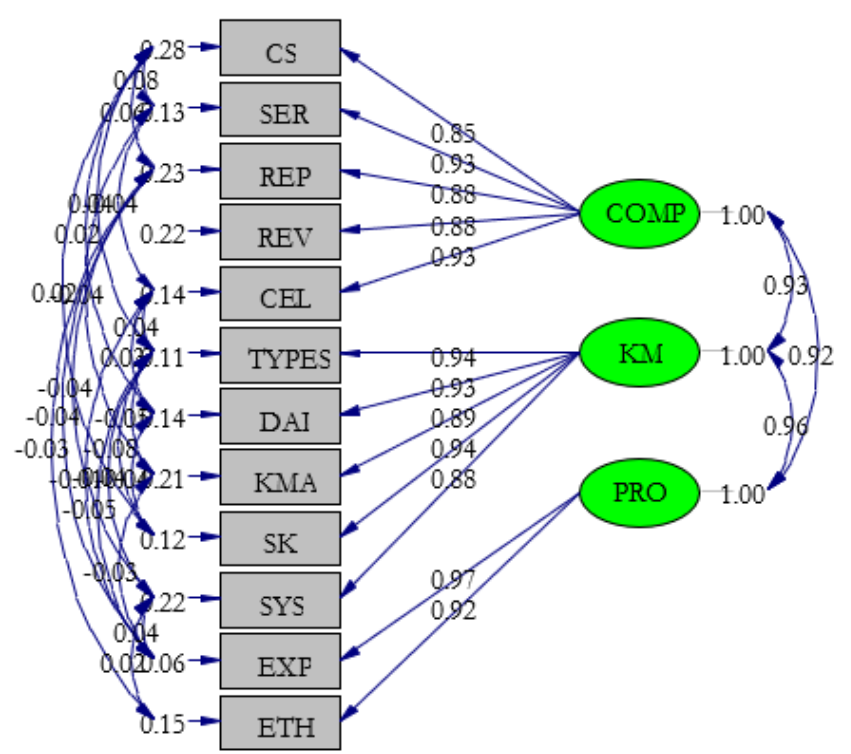

Figure 3. Confirmatory factor analysis of the internal latent variables Chi-Square $\left(\chi^{2}\right)=15.01, \mathrm{df}=30, p$ value $=0.98969, \mathrm{RMSEA}=0.000$.

\subsection{Convergent model analysis}

Results in Figure 4 show that the $\chi^{2}$ value was 45.73, which had 53 degrees of freedom (df). Therefore, the ratio between $\chi^{2}$ and the $\mathrm{df}$ was equal to 0.863 when tested, which showed statistical significance as it was $\geq 0.05$, which confirms the model's hypotheses are not different from the empirical data (Table 4 and Table 6). Further confirmation was established as the results of the GFI equaled 0. 0.98, and the AGFI equaled 0.96. The $p$-value $=0.75$, the RMSEA $=0.000$, and the SRMR $=0.000$. As SRMR is an absolute measure of fit, a value of zero indicates a perfect fit with a value of $<0.05$ indicating a good fit (Hu \& Bentler, 1999).

Table 4

Correlation Coefficients between Latent Variables (Under the Bold Diagonal), the Latency of the Latent

Variable $\left(\rho_{\mathrm{C}}\right)$ and the Average Variance Extracted (AVE)

\begin{tabular}{|l|c|c|c|c|}
\hline Latent Variables & KM & PRO & COMP & CSK \\
\hline Knowledge Management (KM) & $\mathbf{1 . 0 0}$ & & & \\
\hline Professionalism (PRO) & 0.915 & $\mathbf{1 . 0 0}$ & & \\
\hline Competency (COMP) & 0.900 & 0.862 & $\mathbf{1 . 0 0}$ & $\mathbf{1 . 0 0}$ \\
\hline Communications Skills (CSK) & 0.912 & 0.930 & 0.867 & 0.960 \\
\hline$\rho C($ Construct Reliability) & 0.963 & 0.943 & 0.882 & 0.888 \\
\hline$\rho V($ AVE) & 0.840 & 0.893 & 0.800 & 0.943 \\
\hline$\sqrt{\mathrm{AVE}}$ & 0.916 & 0.945 & 0.894 & \\
\hline
\end{tabular}

$*$ Sig. $\leq 0.01$ 


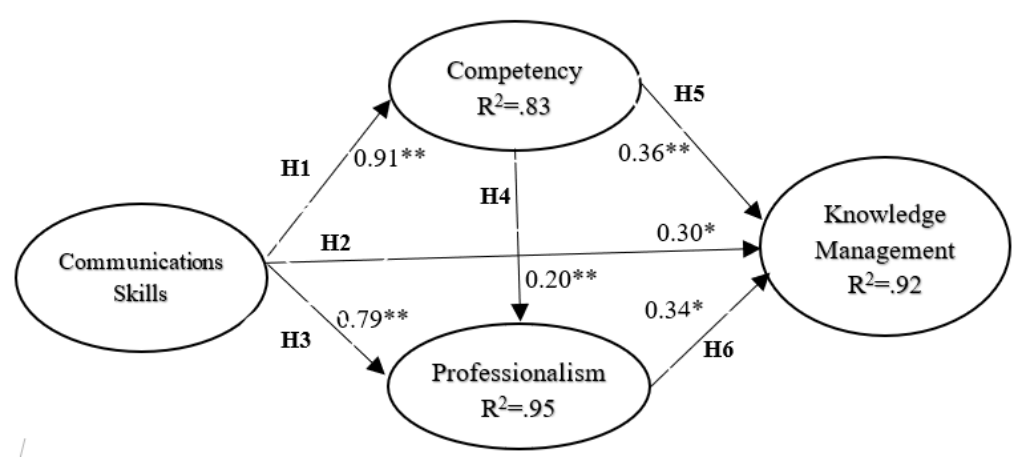

Figure 4. SEM Path analysis of factors affecting knowledge management

Note. $*$ Sig. $\leq 0.05, * *$ Sig. $\leq 0.01$, Chi-Square $=45.73, \mathrm{df}=53, p$-value $=0.75025, \mathrm{RMSEA}=0.000$

Table 5 shows the direct effect (DE), indirect effect (IE), and total effect (TE) of each construct (Zou \& Fu, 2011). Knowledge management (KM) is influenced by the direct and positive contribution of communications skills the most, due to the value of 0.916. Competency and professionalism are also shown to have a direct and positive influence on knowledge management as show by the TEs of 0.43 and 0.34 , respectively. Table 6 shows the results of the hypotheses testing.

Table 5

Standard coefficients of influence in the structural equation model of factors

\begin{tabular}{|c|c|c|c|c|c|}
\hline \multirow{2}{*}{$\begin{array}{l}\text { Dependent } \\
\text { variables }\end{array}$} & \multicolumn{5}{|c|}{ Independents } \\
\hline & & $\mathbf{R}^{2}$ & COMP & CSK & PRO \\
\hline \multirow{3}{*}{ Competency (COM) } & $\mathrm{DE}$ & \multirow{3}{*}{.83} & - & $0.91 * *$ & - \\
\hline & IE & & - & - & - \\
\hline & TE & & - & $0.91 * *$ & - \\
\hline \multirow{3}{*}{$\begin{array}{l}\text { Knowledge Management } \\
(\mathrm{KM})\end{array}$} & $\mathrm{DE}$ & \multirow{3}{*}{.92} & $0.36^{* *}$ & $0.30^{*}$ & $0.34^{*}$ \\
\hline & IE & & 0.07 & $0.66^{* *}$ & - \\
\hline & $\mathrm{TE}$ & & $0.43 * *$ & $0.96^{* *}$ & $0.34 *$ \\
\hline \multirow{3}{*}{ Professionalism (PRO) } & $\mathrm{DE}$ & & $0.20 * *$ & $0.79 * *$ & - \\
\hline & IE & .95 & - & $0.19 * *$ & - \\
\hline & TE & & $0.20^{* *}$ & $0.98^{* *}$ & - \\
\hline
\end{tabular}

$*$ Sig. $\leq 0.05, * *$ Sig. $\leq 0.01, \mathrm{CSK}=$ Communications Skills, $\mathrm{DE}=$ direct effect, $\mathrm{IE}=$ indirect effect, and $\mathrm{TE}=$ total effect

Table 6

Results of Hypotheses Testing

\begin{tabular}{lccc}
\hline \multicolumn{1}{c}{ Hypotheses } & Coef. & t-value & Results \\
\hline $\begin{array}{l}\text { H1: Communications Skills (CSK) has a direct positive influence on Competency } \\
\text { (COM). }\end{array}$ & 0.91 & $17.27^{* *}$ & accepted \\
\hline $\begin{array}{l}\text { H2: Communications Skills (CSK) has a direct positive influence on Knowledge } \\
\text { Management (KM). }\end{array}$ & 0.30 & $2.13^{*}$ & accepted \\
\hline $\begin{array}{l}\text { H3: Communications Skills (CSK) has a direct positive influence on Professionalism } \\
\text { (PRO). }\end{array}$ & 0.79 & $12.27^{* *}$ & accepted \\
\hline $\begin{array}{l}\text { H4: Competency (COM) has a direct positive influence on Knowledge Management } \\
\text { (KM). }\end{array}$ & 0.36 & $6.30^{* *}$ & accepted \\
\hline H5: Competency (COM) has a direct positive influence on Professionalism (PRO). & 0.20 & $3.56^{* *}$ & accepted \\
\hline $\begin{array}{l}\text { H6: Professionalism (PRO) has a direct positive influence on Knowledge } \\
\text { Management (KM). }\end{array}$ & 0.34 & $2.14^{*}$ & accepted \\
\hline$*$ Sig.
\end{tabular}

$*$ Sig. $<0.05, * *$ Sig. $<0.01$, Critical ratios (t-values) more than 1.96 are significant at the 0.05 level. S.E. $=$ standard error, $\mathrm{CR}=$ critical ratio $(\mathrm{t}-\mathrm{value})$ 
Both Hooper et al. (2008) and Hair et al. (2016) discussed low $\mathrm{R}^{2}$ values $(\leq 0.20$ and $\leq 0.25$, respectively), and suggested that they be removed from the analysis as this is an indication of high error rates. All causal factors in the model were therefore shown to have a positive influence on knowledge management, with $92 \%$ of the variance of the factor affecting the knowledge management $(K M)\left(R^{2}\right)$. Ranked in importance, the three latent variables were communications skills (CSK), competency (COMP), and professionalism (PRO), with a total score of $0.96,0.43$, and 0.34 , respectively.

Results from the study (Figure 5 and Table 6) showed that communications skills (CSK) had a direct (0.91) and positive affect $(\mathrm{p} \leq 0.01)$ on competency $(\mathrm{COM})$, which supports hypothesis $\mathrm{H} 1$, which is supported by research from Casner-Lotto and Barrington (2006), which indicated that competency is the ability to use knowledge, facts, and data to solve workplace problems. Study results also agree with the National Association of Colleges and Employers (2015), in which it was determined that written communications skills were viewed as the second most important attribute by employers $(70.2 \%)$, while verbal communication skills were ranked fifth (68.9\%). Also, according to Shannon (2011), the ability to communicate effectively with clients can have an immense impact on a lawyer's practice, and on the success of the law firm as a whole. This is supported by Francis (2016), in which UK legal recruiters stated that if a legal candidate can't hold a conversation in an interview, they most probably are of little value to the firm.

Hypothesis $\mathrm{H} 2$ was also supported in which CSK had a direct and positive influence on KM (0.30), as well as $\mathrm{H} 3$ in which CSK had a direct and positive influence on PRO (0.79). Support for this comes from Crawford and Strohkirch (2006), in which after a survey of 1,046 knowledge workers it was determined that one of the most important characteristics is effective communication, which is consistent with the former US Chief Justice Warren Burger who also repeatedly called upon the legal community to increase the study of communication skills in law schools (Kessler, 1998).

Concerning the technological aspects of communications skills, the Singapore law firm Rajah and Tann have stated the importance of communication technology and is investing heavily in it, making it possible for its lawyers to be truly mobile and available "anytime and anywhere" (Gunashekar, 2017). Technology has made the practice of law more efficient and has also enabled lawyers, both male and female, to integrate work and life.

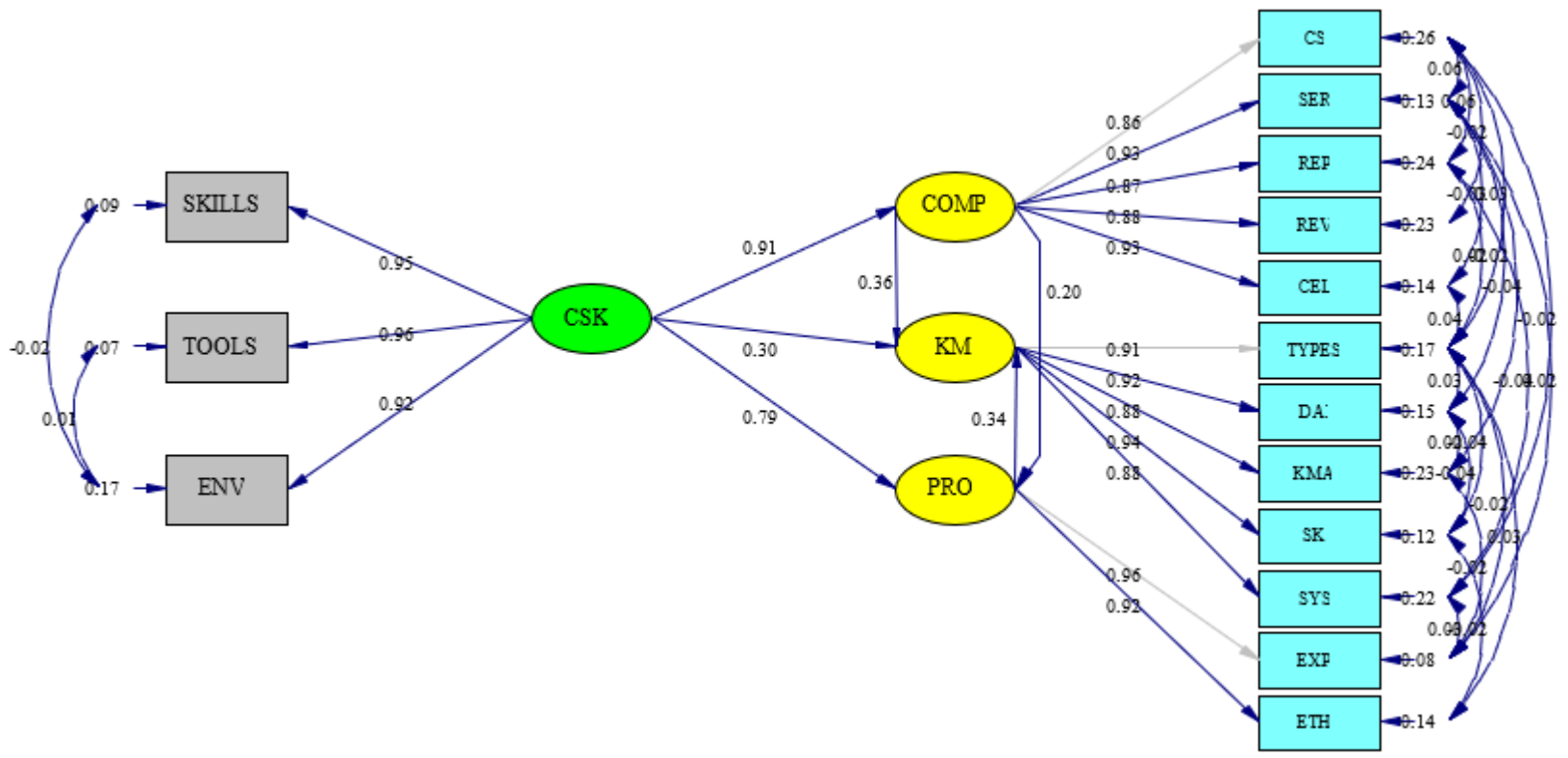

Figure 5. SEM final model with values from estimates $(\mathrm{n}=332)$

Chi-Square $=45.73, \mathrm{df}=53, p$-value $=0.75025, \mathrm{RMSEA}=0.000$ 
Competency (COMP) also had a direct $(0.36)$ and positive influence $(\mathrm{p} \leq 0.01)$ on $\mathrm{KM}(\mathrm{H} 5)$, as well as a direct $(0.20)$ and positive influence $(\mathrm{p} \leq 0.01)$ on PRO (H5). These results are supported by a survey of US organizations (Barrington et al., 2006), from which seven career competencies were identified as essential. At the top of the list was 'professionalism' with an overwhelming 97.5\%.

In the final hypothesis (H6), PRO was determined to have had a direct and positive influence on KM (0.34). Professionalism (PRO) also yielded some interesting results as ethics was overwhelming stated to have the greatest importance in a Thai legal practitioners and consultants' professionalism (mean $=5.71$ ). This is consistent with legal practitioners' requirements from South Australia in which it is stated that lawyers must conduct themselves with integrity, and deal with other members of the legal profession with courtesy and integrity (Legal Services Commission, 2017). Concerning ethics, the study identified the stated importance of both ethics training and ethical behavior within the legal profession. But according to Bairaktarova and Woodcock (2017), the teaching of professional ethics, or motivating students to take professional ethics seriously is not easy.

\section{CONCLUSION}

For the Thai legal consultant, the study has shown that communication skills have become the elephant in the room with regards to knowledge management abilities. The problem is not new however as Thailand for the past two centuries has 'danced' with how much or how little Western countries can influence Thai law, with the language of the law being Thai and those who practice it in 2017, required to be Thai citizens.

However, since the beginning, trade and commerce has been at the core of the debate, and the tugof-war to create a system more flexible to international trade is always in debate. One proven method to replicate expertise is with knowledge management processes and systems, which is becoming a crucial foundation for firms globally. The time has therefore come for re-thinking, re-planning, and re-structuring Thailand's legal infrastructure to create an environment that is friendly to international investment and trade (Chaitrong, 2017). Knowledge management systems are proven, but unfortunately there are many obsolete Thai laws slowing down change and growth (even when KM is implemented), and drafting new business-friendly laws is time consuming. Thailand therefore needs to change its mindset to have a new skill-set and ecosystem as Thailand 4.0 sets off on a path where a new international, digitally based, 2.1 trillion-baht ( $\$ 65$ billion) e-commerce economy is a core pillar of the Kingdom's projected growth (Jones \& Pimdee, 2017; Leesa-nguansuk, 2017). Along with legal reforms, good faith, trustworthiness, communications skills, cultural awareness, and language skills will also play a fundamental role in a Thai legal consultant's knowledge management skills ability.

\section{REFERENCES}

Barrington, L., Casner-Lotto, J., \& Wright, M. (2006). Are they really ready to work? Retrieved from http:/ / tinyurl.com/j2c5uh6

Best, J. W., \& Kahn, J. V. (2003). Research in education (9th ed.). Boston: Allyn and Bacon.

Black, N. (2017a, June 20). ABA Survey: How lawyers communicate and collaborate with clients in 2017. Above the law. Retrieved from http:/ / tinyurl.com/y8fczf65

Black, N. (2017b, June 15). How can law firms meet needs of 21 st century legal clients?. Above the law. Retrieved from http://tinyurl.com/y86sjsw6

Boyatzis, R. E. (1982). The competent manager; A model for effective performance. New York, NY: Wiley.

Buckler, G. (2004, April 12). Knowledge management crucial tool for law firms. The Globe and Mail. Retrieved from http://tinyurl.com/y9n56ykf 
Casner-Lotto, J., \& Barrington, L. (2006). Are they really ready to work? Employers' perspectives on the basic knowledge and applied skills of new entrants to the 21 st Century U.S. workforce. Retrieved from http://tinyurl.com/jeb85zg

Chaimungkalanont, S. (n/d). Cross-border legal services in ASEAN under WTO: A Thai perspective. 80 - 91. Retrieved from http://tinyurl.com/yasy6psd

Chaitrong, W. (2017, September 26). Vested interests block meaningful reforms as government remains too vague: Banthoon. The Nation. Retrieved from http://tinyurl.com/ybr2h2nt

Chen, F., Curran, P. J., Bollen, K. A., Kirby, J., \& Paxton, P. (2008). An empirical evaluation of the use of fixed cutoff points in RMSEA test statistic in structural equation models. Social Methods Research, 36(4), 462 - 494. doi: $10.1177 / 0049124108314720$

Crawford, C. B., \& Strohkirch, C. S. (2006). The critical role of communication in knowledge organizations: Communication apprehension as a predictor of knowledge management functions. Journal of Knowledge Management Practice, 7(4). Retrieved from http://www.tlainc.com/articl122.htm

Deardorff, D. K. (Ed.) (2009). The SAGE handbook of intercultural competence. Thousand Oaks, CA: Sage Publications.

Duff, E., Shiner, M., \& Boon, A., \& Whyte, A. (2000). Entry into the legal professions: the law student cohort study year 6. London, UK: The Law Society.

European Union. (2015). 2015 Joint report of the Council and the Commission on the implementation of the strategic framework for European cooperation in education and training (ET 2020). New priorities for European cooperation in education and training. (2015/C 417/04). Retrieved from http://tinyurl.com/zctcbre

Fan, Y., Chen, J., Shirkey, G., John, R., Wu, S. R., Park, H., \& Shao, C. (2016). Applications of structural equation modeling (SEM) in ecological studies: an updated review. Ecological Processes, 5(19). doi: 10.1186/s13717-0160063-3

Flanagan, J. C. (1954). The critical incident technique. Psychological Bulletin, 51(4). Retrieved from http://tinyurl.com/z8oxxub

Francis, A. (2016). At the edge of law: Emergent and divergent models of legal professionalism. New York, NY: Routledge.

Fukunaga, Y. (2015). Assessing the progress of ASEAN MRAs on professional services. ERIA Discussion Paper Series. Retrieved from http://tinyurl.com/ydbw8nyn

George, D., \& Mallery, P. (2010). SPSS for Windows step by step: A simple guide and reference 17.0 Update (10th Ed.). Boston, MA: Pearson.

Gipps, C., \& Stobart, G. (2003). Alternative Assessment. Vol. 2. Singapore: SAGE Publications.

Giusti, G. (2008). Soft skills for lanyers. London, UK: Chelsea Publishing.

Gomes, J (2001) Knowledge infrastructures in new product development. In 5th International Conference on Technology Policy and Innovation, Delft, Netherlands.

Gunashekar, R. (2017, June 22). Closing the gender divide. Asian Legal Business. Retrieved from http://tinyurl.com/y9g8c3la

Hair, J. F., Hult, G. T. M., Ringle, C. \& Sarstedt, M. (2016). A primer on partial least squares structural equation modeling (PLS-SEM). Thousand Oaks, CA: Sage.

Hooper, D., Coughlan, J., \& Mullen, M. (2008). Structural equation modelling: Guidelines for determining model fit. Electronic Journal of Business Research Methods, 6(1), 53 - 60. Retrieved from http://tinyurl.com/zyd6od2

Hu, L. T., \& Bentler, P. M. (1999). Cutoff criteria for fit indexes in covariance structure analysis: Conventional criteria versus new alternatives. Structural Equation Modeling, 6(1), 1-55. doi: 10.1080/10705519909540118

Jayaphorn, C. (2006). Reformation of the Thai legal system at the beginning of the $20^{\text {th }}$ century: Context and origin. Thailand Law Review, 9(2). Retrieved from http://tinyurl.com/y79mttmp

Jones, C. \& Pimdee, P. (2017). Innovative ideas: Thailand 4.0 and the fourth industrial revolution. Asian International Journal of Social Sciences, 17(1), 4 - 35. https://doi.org/10.29139/aijss.20170101

Jöreskog, K. G., Olsson, U. H., \& Fan, Y. W. (2016). Multivariate analysis with LISREL. Berlin, Germany: Springer Verlag.

Kabene, S. M., King, P., \& Skaini, N. (2006). Knowledge Management in Law Firms. Journal of Information Law and Technology, 1, 1-21. Retrieved from http://tinyurl.com/y88pnx $4 \mathrm{~b}$ 
Kessler, J. B. (1998). The lawyer's intercultural communication problems with clients from diverse cultures. Northwestern Journal of International Law \& Business, 9(1). Retrieved from http://tinyurl.com/y8fs8rbe

Kline, R. B. (1998). Principles and practice of structural equation modeling. New York, NY: Guilford Press.

Krairit, D-J. (n/d). ASEAN legal cross-border practice. Retrieved from http:// tinyurl.com/yac8td43

Lambe, P. (2003). What does KM mean for law firms? Retrieved from http://tinyurl.com/y832abb2

Leesa-nguansuk, S. (2017, September 22). Depa predicts e-commerce to triple to B2.1tn. Bangkok Post. Retrieved from http://tinyurl.com/ycr36mub

Legal Services Commission. (2017). Professional ethics and court etiquette. Retrieved from http://tinyurl.com/y73q5v9u

Likert, R. (1972). Likert technique for attitude measurement. In W. S. Sahakian (Ed.). Social psychology: Experimentation, theory, research. Scranton, PA: Intext Educational Publishers.

Lyman, D. \& Tongmee, A. (2009, October 29). Lawyer's obligation: Confidentiality of client information in Thailand. Prepared for the New York State Bar Association International Section Seasonal Meeting in Singapore Plenary Panel D. Retrieved from http://tinyurl.com/yd9hcfcy

Mahakun, V., Buasri, U., Darasorn, K., \& Chanpetpul, P. (2017). Ethics of the legal profession of Thailand. Social Science Asia, 3(1), 1-16. Retrieved from http://tinyurl.com/y82nr739

Maister, D. H. (2000). True professionalism: The courage to care about your people, your clients, and your career. New York, NY: Touchstone.

Maister, D. H. (2003). Practice what you preach. What managers must do to create a high achievement culture. New York, NY: Free Press.

Mansfield, B. (1989). Competence and standards. In: Competency Based Education and Training. Great Britain: The Falmer Press.

Matveev, A. V. (2016). Intercultural competence in organizations: A guide for leaders, educators and team players. Berlin, Germany: Springer Publishing.

McClelland, D. C. (1973). Testing for competence rather than for intelligence. American Psychologist, 28(1), 1 - 14. doi: $10.1037 / \mathrm{h} 0034092$

Moore, L. (2017). The rise and rise of knowledge management. The Law Society of New South Wales. Retrieved from http://tinyurl.com/y77a3rxp

Myatt, M. (2013, March 28). The most common leadership model - And why it's broken. Forbes Magazine Online. Retrieved from http://tinyurl.com/yco7s323

National Association of Colleges and Employers. (2015). Job Outlook 2016. Retrieved from http://tinyurl.com/h9773yf

Nonaka, I. (Ed.). (2005). Knowledge management: Critical perspectives on business and management, Volume 2. New York, NY: Routledge.

Palma, K. L. (2015). The cross-border legal practice: Thailand and the Philippines. Retrieved from http://tinyurl.com/yd7hfhin

Porter, M. W. (1979, March). How competitive forces shape strategy. Harvard Business Review. Retrieved from http://tinyurl.com/113nczk

Re, E. D. (1982). The lawyer as counselor and the prevention of litigation. Catholic University Law Review, 31 (4), 685 698. Retrieved from http://tinyurl.com/yb8vd4ft

Reeve, E. M. (2016). 21st century skills needed by students in technical and vocational education and training (TVET). Asian International Journal of Social Sciences, 16(4), 65-82. Retrieved from https://doi.org/10.29139/aijss.20160404

Ryan, G., Spencer, L. M., \& Bernhard, U. (2012). Development and validation of a customized competency-based questionnaire: Linking social, emotional, and cognitive competencies to business unit profitability. Cross Cultural Management: An International Journal, 19(1), 90-103. doi: doi: 10.1108/13527601211195646

Sathitsuksomboon, C. (2001). Thailand's legal system: Requirements, practice, and ethical conduct. Thailand Law Forum. Retrieved from http://tinyurl.com/y74vw66p

Shannon, M. P. (2011). Cultivating the art of effective client communications. Law Practice Magazine, 7(5). Retrieved from http://tinyurl.com/ya9n3h89 
Sullivan, W. M., Colby, A., Wegner, J. W., Bond, L., \& Shulman, L. S. (2007). Educating lanyers: Preparation for the profession of law. San Francisco, CA: Jossey-Bass.

Sydney University Law Society Careers Guide (2014). Retrieved from http://tinyurl.com/ychqem9b

Tavakol, M., \& Dennick, R. (2011). Making sense of Cronbach's alpha. International Journal of Medical Education, 2, 53 55. doi: 10.5116/ijme.4dfb.8dfd

Thailand Lawyers Act, B.E. 2528 (1985). Retrieved from http://tinyurl.com/ybb2sur2

UCLA Statistical Consulting Group. (2016). Introduction to Mplus: Featuring confirmatory factor analysis. Retrieved from http://tinyurl.com/jekut29

Wong, K.K-K (2013). Partial least squares structural equation modeling (PLS-SEM) techniques using SmartPLS. Marketing Bulletin, 24. Retrieved from http://tinyurl.com/ybw7xvr3

Zou, S., \& Fu, H. (Eds.) (2011). International marketing: Emerging markets. UK: Emerald Group Publishing. Retrieved from http://tinyurl.com/jnxwjlh 